\title{
Political Attitudes, Means of Safeguarding Rights, and National Identity of Residents in the Border Areas of China
}

\author{
Based on the Investigation of Yunnan Province
}

\author{
Mingyang Ruan \\ Kunming University \\ Kunming, China 650214
}

\begin{abstract}
In the vision of resistance politics in China, the measures of rights protection are divided into two forms: First, to protect human rights in accordance with the law, that is, when endangering their rights, people safeguard their rights by taking measures within the system; second, fighting for rights, that is, protecting their own interests by non-systemized means. Issues related to rights protection involve political attitudes of the public, and it can rise to the height of social stability and national identity, so the study of the topic is conducive to providing an effective path and advice for relevant departments to improve the "popular support", comply with "popular will", and deal with "popular discontent".
\end{abstract}

Keywords-political attitude; means of safeguarding rights; national identity

\section{INTRODUCTION}

In the vision of resistance politics in China, the "survival ethics" and the "weapons of the weak" that Scott sees are surging. In recent years, in the rising individual and group resistance against community affairs, disadvantage groups in the contradiction "take advantage of the game" in the pluralsubject boundary conflict to defend their interests in different ways. Judging from the trend of mass incidents in Yunnan Province in recent years, interest-based protest has become the mainstream. The core of interest-based protest is another topic that has been repeatedly discussed in academic community: channels of interest expression. Under the macroscopic background of a transitional society, it is divided into two forms: First, supporting rights by law, that is, when endangering related interests, people adopt means within the system to protect their rights; second, fighting for rights, that is, people protect interests by non-systemized means, including the traditional petitions, mass protests and the use of interpersonal networks, as well as spreading by the use of modern media networks, Micro Blog, We Chat and other means. At the same time, as a non-institutional means of protest, fighting for rights is undoubtedly the source of group resistance as well as the research focus, and what characteristics of the groups choosing fighting for rights are also should be discussed. In order to further clarify the awareness of the public in fighting and explain the factors that influence the choice of means of safeguarding their rights, the study will introduce the concept of political attitude and use quantitative methods to analyze.

\section{THE CONCEPT AND ClASSIFICATION OF POLITICAL ATTITUDES}

Political attitude has a direct impact on people's choices in fighting political forms and is a kind of belief determining the political participation of groups. As one of modern political science's criteria, Almond defined it as "the cognition and feedback of the part participating in political systems, as well as the emotions and evaluations formed on them." At the same time, Almond pointed out that the formation of political attitudes is related to the socialization of human beings. Family, school, government, and media play a decisive role in the formation of their political attitudes (Almond, 1989). While Stone believes that political attitude is a kind of political values. It can be implemented into political behaviors, and it is maintained for a long time in political organizations and various parties, and finally precipitated as a system" (William Stone, 1987); Chinese scholar Wang Jian believes that political attitudes include the recognition, emotion and evaluation of political systems, and are guided by their political goals (Wang Jian, 2001); Lei Fang believes that political attitude is a kind of social psychology, including people's national identity, views on the social system and the government, and their cognition and evaluation of their own positions in political life (Lei Fang, 2012); Li Xi thinks that political attitude is composed of political awareness, political emotion, and political motivation. It reflects people's political beliefs and faith, and is a continuous, stable political psychological complex $(\mathrm{Li} \mathrm{Xi}$ 2012).

Judging from the classification of political attitudes, different scholars have different opinions. Almond divided it into three aspects: political cognition, political emotion and political evaluation; Chinese scholar $\mathrm{Li} \mathrm{Yi}$ believes that political attitude covers three dimensions: degree of satisfaction and confidence on the local government, and evaluation of social Issues (degree of fairness) ( $\mathrm{Li} \mathrm{Yi,} \mathrm{2011);}$ 
Li Chunling also has similar views, and she thinks that satisfaction and identification on the state and government, and sense of fairness are the cores of political attitudes ( $\mathrm{Li}$ Chunling, 2012); In 2006, the Chinese Academy of Social Sciences measured political attitudes from five dimensions, including personal feelings, feelings of security, political credibility, national identity, and group resistance (Chinese Academy of Social Sciences, 2006).

To sum up, the study believes that political attitude is a system of political values developed by human beings. It includes subjective emotions, perceptions, and evaluations of political subjects for political objects, and shapes the trend of people's political participation and political behaviors. Looking from the measurement of political attitude, and considering the availability of data collection, scientificity of the questionnaire design, and sensitivity of questions, the study divided political attitudes into four measurement dimensions: democratic awareness, national identity, and group conflict awareness and sense of social justice. The related researches on political attitudes can reveal the conflict consciousness of group resistance indirectly and directly, which help to explain the trade-off between people's supporting rights by law and fighting for rights, and further analyze the influencing factors of their choices.

\section{DATA SOURCES AND StATISTICAL METHODS}

The research group adopted sampling methods and questionnaire methods to measure and collect relevant public opinions in order to fully reflect the scientificity, accuracy and credibility of the research. The survey started on December 23, 2016 and ended on March 17 2017, and it was conducted by urban and rural residents in Yunnan Province. The survey covered a range of issues such as gender, age, level of education, income, and political attitudes of urban and rural residents. A total of 1200 households were investigated, and the number of respondents was 3,217. The survey area covers 16 cities in Yunnan Province. A total of 1054 questionnaires were obtained, of which 810 were valid. The effective rate of the questionnaires is $76.85 \%$.

There are mainly three statistical methods for political attitudes and means of safeguarding rights used in the study, including description analysis and regression analysis. Descriptive analysis is mainly used to explain the internal structure, dimensions, and distribution of independent variables, control variables, and dependent variables, to describe political attitudes, individual basic characteristics, and the basic status of rights protection measures; regression analysis is used to explain How do political attitudes (independent variables) and individual basic characteristics (control variable) affect people's choices of rights protection methods? And the survey verifies the proposed hypothesis one by one. Data processing is fully computerized. The statistical software is EXECEL, SPSS17.0 software package and STATA software.

\section{OPERATIONALIZATION OF VARIABLES}

There are 13 items listed about political attitudes in the questionnaire. According to the 13 questions listed, the opinions of the respondents were collected, and the questionnaire adopted a measuring scale of five points. The respondents choose from "fully agree", "agree", "substantially agree", "disagree" and "completely disagree", scoring 5 to 1 points, respectively. Since the implication of items $10,11,12$, and 13 is opposite to others, assignment conversion is required.

Through exploratory factor analysis of 13 questions through SPSS17.0, we can find that the each indicator is suitable as a structural indicator of political attitudes. Through the analysis on the principal components of each index by the method of exploratory factors analysis, and orthogonal rotation of factor loading by the use of variance maximization, there were a total combinations of four factors whose eigenvalues exceeded 1 , which respectively are the factor of democratic consciousness, factor of national identity consciousness, factor of social fairness consciousness, and factor of group conflict consciousness. The studies are respectively represented by $\mathrm{P} 1, \mathrm{P} 2, \mathrm{P} 3$, and P4, seeing "Table I". From "Table I", it can be seen that the common factor variance reaches more than 0.5 containing all the dependent variable indicators. The total percentage of contribution rate on all factor variances is $66.19 \%$. Through the KMO test, a test value of 0.817 was obtained and the test value was less than one. Using the "Bartlett ball test", the test data reached 5,435.15 ( $\mathrm{P}<0.001)$. The above-mentioned statistical significance test and variance analysis showed that all the above 13 variable indicators are suitable for factor analysis. The specific analyses on the combination of the four dependent variable factors are as follows: 
TABLE I. SCORES AND Factor ANalysis Results of URban AND RuRal Residents' Political AtTitudes IN YunNan Province (NonSTANDARDIZED BETA VALUES)

\begin{tabular}{|c|c|c|c|c|c|c|c|}
\hline & $\begin{array}{l}\text { Average } \\
\text { value }\end{array}$ & $\begin{array}{l}\text { Standard } \\
\text { deviation }\end{array}$ & $\begin{array}{l}\text { P1 } \\
\text { Democracy } \\
\text { Awareness }\end{array}$ & $\begin{array}{l}\text { P2 } \\
\begin{array}{c}\text { State } \\
\text { recognition }\end{array}\end{array}$ & $\begin{array}{l}\text { P3 } \\
\text { Society } \\
\text { fairness }\end{array}$ & $\begin{array}{l}\text { P4 } \\
\text { Group } \\
\text { conflict }\end{array}$ & Communality \\
\hline $\begin{array}{l}\text { When you suffer injustice, you } \\
\text { will join as soon as possible if } \\
\text { someone helps you against the } \\
\text { unfairness }\end{array}$ & 3.64 & 1.331 & 0.025 & 0.111 & 0.134 & 0.897 & 0.835 \\
\hline $\begin{array}{l}\text { There is a conflict between } \\
\text { urban and rural areas, the poor } \\
\text { and the rich, the bottom and } \\
\text { upper groups, the general staff } \\
\text { and managers }\end{array}$ & 3.26 & 1.342 & 0.073 & 0.246 & 0.094 & 0.869 & 0.829 \\
\hline $\begin{array}{c}\text { There are more or less } \\
\text { segregation and contradictions } \\
\text { between urban and rural areas, } \\
\text { ethnic groups, local people } \\
\text { and strangers }\end{array}$ & 2.76 & 1.547 & 0.155 & 0.461 & 0.134 & 0.334 & 0.394 \\
\hline $\begin{array}{l}\text { You are proud of being a } \\
\text { citizen of the People's } \\
\text { Republic of China }\end{array}$ & 3.2 & 1.217 & 0.077 & 0.749 & 0.293 & 0.15 & 0.675 \\
\hline $\begin{array}{l}\text { Most policies and initiatives } \\
\text { issued by the government } \\
\text { reflect public opinions }\end{array}$ & 2.92 & 1.349 & 0.182 & 0.825 & 0.189 & 0.113 & 0.762 \\
\hline $\begin{array}{l}\text { You are satisfied with the } \\
\text { current operating mechanism } \\
\text { of China }\end{array}$ & 2.43 & 1.426 & 0.332 & 0.666 & 0.007 & 0.115 & 0.567 \\
\hline $\begin{array}{l}\text { Democracy is that the } \\
\text { government doing things for } \\
\text { the sake of the public }\end{array}$ & 1.94 & 1.555 & 0.679 & 0.256 & -0.04 & -0.033 & 0.529 \\
\hline $\begin{array}{l}\text { Everyone has the right to } \\
\text { speak and decide on the affairs } \\
\text { of the state and the } \\
\text { government }\end{array}$ & 2.8 & 2.116 & 0.89 & 0.079 & 0.167 & 0.032 & 0.826 \\
\hline $\begin{array}{c}\text { Only people with knowledge } \\
\text { and status can participate in } \\
\text { national and government } \\
\text { affairs }\end{array}$ & 3.31 & 1.957 & 0.82 & 0.117 & 0.251 & 0.105 & 0.76 \\
\hline $\begin{array}{l}\text { Regardless of their status, } \\
\text { everyone has the right to } \\
\text { participate in politics }\end{array}$ & 2.86 & 1.84 & 0.686 & 0.202 & 0.202 & 0.095 & 0.562 \\
\hline $\begin{array}{l}\text { The amount of money is in } \\
\text { direct proportion to one's } \\
\text { effort, and it is fair }\end{array}$ & 2.88 & 1.336 & 0.221 & 0.183 & 0.74 & 0.019 & 0.629 \\
\hline $\begin{array}{c}\text { The rich should pay more } \\
\text { taxes, while the poor should } \\
\text { pay less }\end{array}$ & 3.26 & 1.375 & 0.176 & 0.168 & 0.803 & 0.073 & 0.71 \\
\hline $\begin{array}{l}\text { Poor children are more } \\
\text { difficult to show up than the } \\
\text { rich }\end{array}$ & 3.71 & 1.291 & 0.05 & 0.121 & 0.685 & 0.199 & 0.526 \\
\hline Eigenvalues & & & 4.632 & 1.768 & 1.195 & 1.009 & \\
\hline $\begin{array}{c}\text { Differences of explaining } \\
\text { variable }(\%)\end{array}$ & & & 35.63 & 13.603 & 9.191 & 7.764 & \\
\hline $\begin{array}{c}\text { Accumulation of explaining } \\
\text { variable }(\%)\end{array}$ & & & 35.63 & 49.233 & 58.424 & 66.188 & \\
\hline
\end{tabular}

In P1, 4 indexes (items 1, 2, 3, 4) have the highest loading values, reaching $0.679,0.89,0.82$, and 0.686 , respectively, representing P1 well. Judging from the contents involved in the indicators, the contents of the four projects belongs to the category of democratic rights. Therefore, we named P1 as a factor of "democratic consciousness".

P2 is mainly represented by 4 indexes of items $5,6,7$, with loading values of $0.749,0.825$, and 0.666 , respectively. The three indicators are related to the attitudes and opinions of the urban and rural residents on the state and the government. Therefore, we named the factor "national identity".

In $\mathrm{P} 3$, the factor loading values for items 8,9 , and 10 were $0.74,0.803$, and 0.685 , respectively, which represented P3 well. The three indicators mainly concern people's views on social equity. Therefore, we named P3 as a factor of "socially fair".

P4 is mainly represented by two indicators 11 and 12 and the factor loading values are as high as 0.897 and .0869 respectively. The contents reflected by the two indicators are related to the concept and attitude of group conflict 
Therefore, we named P4 as a factor of "group conflict awareness".

\section{Political Attitudes, Means of SAFEguarding RIGHTS, AND THEIR INFLUENCING FACTORS}

The 810 valid samples collected by the questionnaire basically reflect the political attitudes and means of safeguarding rights of urban and rural residents in Yunnan Province. Through descriptive analysis, basic conditions of independent variables and dependent variables can be answered, while the relationship model between political attitudes means of rights protection, and basic characteristics of individuals, as well as how political attitudes influence the choice of safeguarding rights methods need to be explained by the model of regression analysis.

Considering means of safeguarding rights, as dependent variables, are dichotomous variables, the study intends to use Logistic regression methods to construct the model in order to explain the risk probability of different means of safeguarding rights. According to the research purpose, there are mainly two core questions that the study needs to answer. First, whether political attitudes have an effect on the choices of means of safeguarding rights; second, whether there is a significant difference between defending rights according to law and fighting for rights. For this purpose, the model respectively introduced thirteen variables in four dimensions including five control variables: gender, age, educational status, monthly income, and urban and rural identities; and the independent variable: political attitudes to work as the means of safeguarding rights and fusion factors for dependent variables so as to establish Logistic regression equation and formed two models eventually. Model 1 shows the risk probability of supporting rights by law under various factors. Model 2 is completely related to model 1 in terms of structure and meaning, but it shows the risk probability of fighting for rights under different influences seeing "Table II" and "Table III".
TABLE II. THE REGRESSION MODEL OF SUPPORTING RigHTS BY LAW OF THE RESIDENTS IN URBAN AND RURAL AREAS IN YUNNAN PROVINCE

\begin{tabular}{|c|c|c|}
\hline variable & Model 1 & \\
\hline Control variable & $\begin{array}{l}\text { Coefficient } \\
\operatorname{Exp}(\mathrm{B})\end{array}$ & Standard error S.E \\
\hline gender & $0.350 * * *$ & \\
\hline age & $0.039 * * *$ & 0.178 \\
\hline degree of education & 0.067 & 0.241 \\
\hline politics status & $0.121 * *$ & 0.106 \\
\hline monthly income & 0.538 & 0.953 \\
\hline Urban and rural identity & 0.128 & 0.656 \\
\hline \multicolumn{3}{|l|}{ independent variable } \\
\hline $\begin{array}{c}\text { consciousness of Group } \\
\text { conflict }\end{array}$ & -0.078 & 0.451 \\
\hline national identity & $0.150 *$ & 0.235 \\
\hline sense of democracy & $0.432 *$ & 0.125 \\
\hline sense of social justice & 0.026 & 0.354 \\
\hline \multicolumn{3}{|l|}{ other parameters } \\
\hline intercept constant & $-3.182^{* *}$ & \\
\hline degree of freedom d.f. & 6 & \\
\hline Sig. & 0.03 & \\
\hline chi-square value Wald & 17.866 & \\
\hline -2Log likelihood value & 867.889 & \\
\hline
\end{tabular}

Judging from several parameters adopted: Coefficient of incidence, standard error, chi-squared value, saliency coefficient, and log-likelihood value and their corresponding degrees of freedom, model 1 and 2 have higher fitting degree. Model 1 shows the verification of the factors affecting the form of supporting rights by law. From the perspective of model 1, the educational level, income, and urban-rural identity among variables of demographic characteristics are not statistically significant for people choosing supporting rights by law, while gender, age, and politics status have a very significant impact on the choice of measures of supporting rights by law. The significance level $\mathrm{P}$ is less than 0.01 . From the perspective of gender, when other variables remains the same, the probability that men adopt the measures of supporting rights by law is 1.42 times that of the female with the women as the control group ( calculation methods for probability: eB-1same calculation method in the following), From the perspective of age, when the age increases by 1 year, the tendency of rights protection according to the law increases by $3.98 \%$; from a political perspective, compared with non-members, the probability that party members choose to protect their rights according to the law is $12.86 \%$ higher than non-party members.

From the perspective of political attitudes, there are two reaching a significant level, democracy awareness $(\mathrm{P}<0.05)$ and national identity $(\mathrm{P}<0.05)$, both of which have a significant impact on people's choice of supporting rights by law. Among them, the improvement of citizens' democratic awareness has particularly strong influence on their choice of supporting rights by law. 
TABLE III. THE REgRESSION MODEL OF FIGHTING FOR RIGHTS OF URBAN AND RURAL RESIDENTS IN YUNNAN PROVINCE

\begin{tabular}{|c|c|c|}
\hline variable & Model 2 & \\
\hline Control variable & $\begin{array}{c}\text { Coefficient } \\
\text { Exp(B) }\end{array}$ & $\begin{array}{c}\text { Standard } \\
\text { error S.E }\end{array}$ \\
\hline gender & $0.531^{* * *}$ & \\
\hline age & $-0.028^{* * *}$ & 0.342 \\
\hline degree of education & 0.067 & 0.542 \\
\hline politics status & $-0.021^{* *}$ & 0.117 \\
\hline monthly income & 0.538 & 0.359 \\
\hline Urban and rural identity & 0.128 & 0.536 \\
\hline independent variable & & 0.154 \\
\hline consciousness of Group & $0.062^{*}$ & 0.532 \\
\hline conflict & 0.310 & 0.251 \\
\hline national identity & $0.252^{*}$ & 0.453 \\
\hline sense of democracy & $0.014 * *$ & \\
\hline sense of social justice & & \\
\hline other parameters & $-4.532^{* *}$ & \\
\hline intercept constant & 6 & \\
\hline degree of freedom d.f. & 0.12 & \\
\hline Sig. & 25.76 & \\
\hline chi-square value Wald & 797.832 & \\
\hline -2Log likelihood value & b. Note: * p $<0.05, * 0.01, * * 0.00$
\end{tabular}

Model 2 shows the verification of the factors that influencing the form of fighting for rights. From the perspective of model 2, among all the demographic characteristics variables, educational level, income, and urban-rural identity are still not statistically significant for people's choice on supporting rights by law, but they work in concert with model 1 for gender, age, and political status have a very significant impact on fighting for rights. Among those, the significance level $\mathrm{P}$ of gender and age were all less than 0.001 and the political level was less than 0.01. Judging from the incidence coefficient, different from model 2 , the effect of age on opposing rights is reversed. Age increases year by year, the tendency of protesting rights protection decreases by $2.84 \%$. This trend is consistent with "people tend to support rights by law with the growth of age" in model 1and it is two sides of the same; from the gender perspective, men have "dual character" in the choice of the means of resistance, and the probability of adopting the means outside the system is higher than that of legalization. Specifically, under the control of other variables, using the female as the control group, the probability of the males fighting for rights is 1.7 times that of the females, which is significantly higher than that of the " 1.42 times that of the males supporting rights by law". From a political perspective, compared with non-party members, the probability of party members choosing to fight for rights is $2.12 \%$ lower than that of non-party members.

From the perspective of political attitudes, there are three reaching significant levels, which are awareness of group conflict $(\mathrm{P}<0.001)$, democratic awareness $(\mathrm{P}<0.001)$, and awareness of social justice $(\mathrm{P}<0.01)$. They have a significant effect on the implement of fighting for rights.

\section{CONCLUSION}

After statistical analysis, the following conclusions can be formed: First, gender is one of the important factors that affect the Interest struggle of urban and rural residents in Yunnan Province. Compared with women, men are more likely to "support their rights by law" and "fight for their rights" when their interests are damaged. In other words, men's right-protection awareness is generally higher than that of women. The finding can be attributed to the family authority structure of "Patriarchy", the public generally accepted the values of "equality of men and women". But affected by the traditional concepts, the right of speech in a family is still in the hands of men, and adult men are the main support, representatives of interests and spokespersons in families. Compared with men, women in the interviewed families were conservative in the fighting, and were willing to hand the dominance of "contentious Politics" to men.

Second, age is another important factor affecting the fighting for interests of urban and rural residents in Yunnan Province. Age has a significant impact on the means of safeguarding rights. Specifically, increasing with age, people tend to safeguard their rights in accordance with the law, and are more likely to choose to fight for their rights with age decrease. According to further analysis, age, as a "time index" of human socialization, can be used to evaluate the face of people in different periods of life. In the youth, social mentality of human has not yet matured and is in an irrational period. Affected by collective consciousness, it is prone to produce negative emotions such as impulsivity and anger, and behaviors such as violence, dissatisfaction, and hostility occur frequently, so people tend to fight for rights. Increasing with age, people's experience is also growing, and the imprint of social rules on individuals is also growing. As a result, adults are more tolerant and sensible when encountering injuries. Thereupon, they tend to choose to support their rights by law.

Third, democratic awareness is the main factor affecting means of safeguarding rights of urban and rural residents in Yunnan Province. Judging from the results of statistical analysis, the democracy awareness is positively related to the two methods of safeguarding rights. With the increase of democracy awareness of the public, people are more likely to choose the two methods of safeguarding rights. Democracy consciousness has a profound impact on resistance in political participation of the public. It has been seen everywhere in the public's daily life whether it is "rational rights protection", "unreasonable petition" or "daily resistance" in group resistance. Therefore, it is necessary to establish a public space for citizens to participate in political discussions and establish a sound mechanism of interest expression.

Fourth, political status has a very significant impact on rural and urban residents in Yunnan Province choosing the methods of safeguarding rights. The party members tend to choose the law-based resistance to safeguard their interests. This result shows that the party members are supporters of the existing political system and legal system, and they have a higher sense of identity for legalized system and institution, as well as a strong dependence on the existing system at the same time. Further analysis shows that the status of party members is not only the embodiment of political identity but also the embodiment of the status within the system. 
"Institutional complex" of party members can also be regarded as a continuation of "unit complex". From the perspective of social stratification, the majorities of civil servants, personnel of state-owned enterprises and public institutions with the membership of party members are in "middle class" in all classes, and are also vested interest groups attached to the state. They have special trust toward the state and the government. The special trust makes it easier for the group to choose more moderate and more legitimate ways of safeguarding interests in interest conflict.

Fifth, national identity has a significant impact on the choices of urban and rural residents in Yunnan Province on supporting rights by law. There is a positive correlation between the two. The higher the sense of national identity, the higher the tendency of people supporting rights by law. The sense of national identity is essentially a sense of government trust. It can also be subdivided into the recognition of the central government and local governments. The investigation of national identity in the survey mainly focused on the local government. However, people's recognition on local governments is generally low, scoring only 2.83 points.

Sixth, the sense of social justice has a significant impact on the choice of residents in urban and rural areas in Yunnan Province on fighting for rights, and the two are positively related. The statistical results show that with the improvement of residents' sense of social justice, the possibility that people choose to fight for rights may increase. Based on the survey results, from the perspective of the two indicators involved in positive sense of fairness, the average score is 3.07 points, which shows that people are neutral about the fairness of society. They neither agree with the high nor the low level of social fairness. Judging from an index of reverse sense of fairness, the score is 3.71 points, indicating that the public believes that there is inequality in the current society. According to further analysis, the sense of social justice is essentially the public's perception and evaluation of their own "positional sensibility" and social environment. As Bourdieu puts it: "The most unique pain and burial of dissatisfaction of men and women can all be found their roots in the dilemma of mankind" (Budier, 1989). This situation is a class conflict in the eyes of Marx, but is called social conflict in Coser. The most reasonable way to establish social equity and resolve conflicts is to establish a "social security valve" mechanism that is based on social division. Conflicts and disputes help people establish their understanding of identity boundaries of their own groups. Therefore, as long as the rebellious behaviors are beneficial and controllable, they should not be blocked blindly.

Seventh, the awareness of group conflict has a significant impact on the public's choice on fighting for rights. The statistical results show that the stronger the awareness of group conflict, the higher the probability that people choose to fight for rights. The survey results show that the group conflict consciousness of respondents scores 3.22 points, indicating that people's awareness of conflict is not strong, but it is also above the reference level. This result shows that people have the tendency to participate in contentious politics behaviors, but it is not yet obvious. Therefore, it is necessary to establish a good institutional environment for residents' legitimate protection of rights, actively promote reasonable enforcement, and establish and perfect administrative supervision mechanisms so as to open up a fertile land for protecting rights by law.

\section{ACKNOWLEDGEMENT}

This paper was supported by humanities \& social sciences fund program of China's ministry of education "Study on the treatment models of Group Resistance in ethnic minority areas in the borderland-Taking Yunnan Province as an Example" (12YJC840030).

\section{REFERENCES}

[1] Xiang Liangyun. The Social Cognitive Strategy and Process of the Fuse Incident [J]. Journal of Intelligence, 2011, (6). 向良云.导火索 事件的社会认知策略与过程 [J].情报杂志，2011，（6）。

[2] Zheng Qingjie. The framework of "Intersubjectivity - intervention": The Reflection Spectrum of Qualitative Researches [J]. Society, 2011, (3). 郑庆杰. “主体间性一干预行动” 框架：质性研究的反思谱系 [J].社会, 2011, （3）

[3] Waters. Modern Sociological Theory [M]. Beijing: Huaxia Publishing Press, 2000. 沃特斯. 现代社会学理论 [M]. 北京: 华夏出版社, 2000.

[4] Zheng Hangsheng. New Introduction to Sociology [M]. Beijing: China Renmin University Press, 2002. 郑杭生.社会学概论新修 [M]. 北京: 中国人民大学出版社, 2002.

[5] Yu Jianrong. Main Types and Basic Characteristics of Current Group Events in China [J]. Journal of CUPL, 2009, (6). 于建嵘.当前我国群 体性事件的主要类型及其基本特征 [J]. 中国政法大学学报, 2009, （6）

[6] China's Gini Coefficient is 0.473 , Which Is Higher Than the International Warning Line [EB/OL]. Netease Finance Channel, 2014-1-21. 中国基尼系数 0.473 , 高于国际警戒线 [ EB /OL ].网易 网财经频道, 2014-1-21.

[7] Yu Jianrong. Interest Games and Resistance Politics [J]. Journal of China Agricultural University (Social Sciences Edition), 2009, (1). 于 建嵘.利益博弯与抗争性政治 [J].中国农业大学（社会科学版）, 2009, (1).

[8] Yu Jianrong. Study on Group Psychology in Social Vent Events [J]. Journal of Beijing Administrative College, 2009, (1). 于建嵘.社会泄 愤事件中群体心理研究 [J].北京行政学院学报, 2009, (1).

[9] Yu Jianrong. Main Types and Basic Characteristics of Current Group Events in China [J]. Journal of CUPL, 2009, (6). 于建嵘.当前我国群 体性事件的主要类型及其基本特征 [J]. 中国政法大学学报, 2009, （6）.

[10] Wu Liang. Study on Ethnic Minority Mass Events and Governance Mechanisms in China [D]. Doctoral Thesis of Minzu University of China, 2011. 吴亮. 中国少数民族群体性事件及治理机制研究 [D]. 中央民族大学博士论文，2011.

[11] Waters. Modern Sociological Theory [M]. Beijing: Huaxia Publishing Press, 2000. 沃特斯.现代社会学理论 [M].北京：华夏出版社, 2000.

[12] Yu Jianrong. Interest Games and Resistance Politics [J]. Journal of China Agricultural University (Social Sciences Edition), 2009, (1). 于 建嵘.利益博弯与抗争性政治 [J].中国农业大学（社会科学版）, 2009, (1).

[13] Zhang Chunxia et al. Infiltration of Foreign Religions and Ideology Security in Xinjiang [J]. Social Sciences in Xinjiang, 2009, (10). 张 春霞等. 境外宗教渗透与新疆意识形态安全 [J]. 新疆社会科学, 2009, （10）

[14] Wu Liang. Study on Ethnic Minority Mass Events and Governance Mechanisms in China [D]. Doctoral Thesis of Minzu University of 
China, 2011. 吴亮.中国少数民族群体性事件及治理机制研究 [D]. 中央民族大学博士论文, 2011 . 